「計測自動制 御学会論文集

[ Vol.42, No.8, 982/990 (2006) ]

\title{
EMG センサスーツのためのロバスト関節トルク推定と高速較正
}

\author{
鈴 木 洋 輔*・田 中 孝 之** \\ マリア Q.フェン***・諸 麦 俊 司****
}

Robust Joint Torque Estimation for Using EMG Sensor Suit and High-speed Calibration

\author{
Yousuke SuZukI*, Takayuki TANAKA**, \\ Maria Q. Feng ${ }^{* * *}$ and Shunji Moromugr ${ }^{* * * *}$
}

\begin{abstract}
A robust torque estimation system is developed for soft sensor suits embedded with Electromyogram (EMG) and a variety of sensors for measuring human muscle activities. The sensor suits serve as a man-machine interface for human power amplification. This paper focuses on the EMG part of the sensor suits to study the fundamental issue of torque estimation based on the sensor readings. A robust torque estimation system is developed in this study based on neural networks, where an universal database, rather than individual database for each operator, is proposed and as a result, the calibration time is dramatically decreased. The proposed system can also compensate for sensor positioning errors and individual differences.
\end{abstract}

Key Words: sensor suit, EMG, robust torque estimation, high-speed calibration

\section{1. 緒言}

ロボットメカトロニクス技術の有効なアプリケーションの 一つとして装着型増力装置や遠隔操縦型ロボットなどの人間 機械システムが注目を浴びている。この分野では，メカニズ ムや制御法などのほか，正確な人間の動作や操作力の検出手 法の確立が重要課題となっている。 その 1 手法として, 筋電 位（以下 EMG）や脳波などの生体信号を入力とし，関節卜 ルクや動作意図の計測を目的としたヒューマンインタフェイ スが研究されているたとえば 1),2)。一方, リハビリテーション やスポーツ科学分野においても, 人間の動作とともに, 筋活 動量を計測することによって，人体のメカニズム解析や効果 的なトレーニング法などの研究が行なわれている ${ }^{3)}$.

われわれは人間機械システムの沉用的ヒューマンインタフェ イスおよび運動計測機器としての用途をもつセンサスーツを 提案してきた ${ }^{4)}$. センサスーーツは筋活動測定のための小型セ ンサデバイスが内蔵された伸縮性の高いスーツであり，どの ような人にも簡単に装着できる特徵を有する。本研究では,

* 電気通信大学 調布市調布ヶ丘 1-5-1

** 北海道大学 札幌市北区 14 条西 9 丁目

****カリフォルニア大学アーバイン校

**** 長崎大学 長崎市文教町 1-14

* The University of Electro-Communications

*** Hokkaido University

*** University of California, Irvine

**** Nagasaki University

(Received September 2, 2005)

(Revised March 9, 2006)
EMG センサを内蔵したセンサスーツにおける運動計測，特 に関節トルク推定システムについて論ずる.

ここで EMG は筋の活動状態を知ることができ，人体の発 揮する力を推測することができる情報として，さまざまな分 野で古くから研究されてきた。たとえば，梶谷は EMGのパ ターン認識を GA(Genetic Algorithm) を用いて行ない, 義 手のインターフェイスに応用した ${ }^{5)}$ 。また，森田らも $\mathrm{EMG}$ からニューラルネットワーク $(\mathrm{NN})$ を用いて, 手の開閉動作, 手首関節の掌屈, 背屈動作の関節駆動卜ルクを求める義手の 操作方法を提案している ${ }^{6)}$. EMG を用いた人体動作の推定 システムには NN が多く使われて扔り，小池らは NNを用い て肩関節，时関節において EMGを入力としたフォワードダ イナミグスモデルを作成し，手先の起動生成，関節トルク推 定を行なった。また作成した NNを解析することによって， 解剖学的に求めた筋肉と関節トルクの関係と NN の構造が一 致することを確認している7)。これらのほかにも EMG から 推定できる情報があり, EMGのスペクトル変化と筋の疲労 状態に関連性があることが知られている ${ }^{8)}$.

このように, EMG センサは非侵襲な生体センサとしてそ の有効性を大いに発揮してきたが，センサと皮膚のインピー ダンスや神経支配帯の影響に個人差があることや，測定位置 誤差が測定データに与える影響が大きいなどの問題点があり， センサの貼付にはある程度の熟練が必要とされている。

これら表面 EMGの問題点にに対しては，木竜らが提案し ている神経支配帯位置を動的に推定することによって，その 個人差のよる信号への影響を軽減する手法 ${ }^{9)}$ やさざまな解 析手法を用いることによって, システムの推定精度, 構築速 
度の上昇を目指した研究が行なわれてきた ${ }^{10)}$.

本研究ではスーツにセンサを内蔵することから，従来のよ うに皮膚にセンサを固定する方法に比べ，これらの問題が顕 著に表われる，そのため，EMG センサを主体とする非侵襲 生体セン开を用いた運動計測では, 個人差や測定位置誤差の 影響を明らかにし，それらを較正および補正するシステムが 必要である。

以上より，本研究では下肢 EMG センサスーツによる関節 トルク推定を実現するために，重回帰分析または NNを用い て大腿部 EMG から膝関節トルクを推定するシステムを構築 し, 個人差や測定位置誤差が推定システムにおよほす影響につ いて検証する。また, 複数の被験者から求めた一般的な $\mathrm{EMG}$ と関節トルクの関係を学習する共有 $\mathrm{NN}$ を提案し, 個人差や 測定位置誤差に対してロバストな推定システムを構築し，か つ推定シスデムの高速較正を実現する。これらの有効性を実 験的に検証する.

\section{2. センサスーツ}

\section{1 センサスーツの特徴}

Fig. 1 にセンサスーツの概要図を示す. センサスーツは伸 縮性の高い素材に，筋活動測定のための小型センサデバイス を内蔵し, 全身の関節トルクおよび関節角度の測定を目的とし たウェアラブル運動計測システムであり，つぎの特徴をもつ.

（1）伸縮性のあるスーツにセンサを内蔵することで，だ れにでも容易に装着できる

（2）装着から較正まで，短時間での測定準備が可能

（3）ダイナミックな運動を広範囲で計測できる

（4）数種のセンサ情報を融合することで，ロバストな運 動計測を実現する

スーツに内蔵するセンサデバイスには，主に筋活動を測定す るための EMG センサ，表面筋硬さセンサ ${ }^{11)}$ ，超音波筋活動 センサ ${ }^{12)}$ ，主に動作測定に用いるシェイプセンサ，加速度セ ンサなどがあるが，本研究では EMG センサのみ内蔵したセ ンサスーツ（以下，EMG センサスーツ）について扱い，特 に特徴 (1) および (2) の観点から, 下肢 EMG センサスーツ の膝関節トルク推定システムおよび高速かつ高精度な較正手 法について論ずる.

\subsection{EMG センサスーツ}

センサスーツの特徴上, EMG センサスーツによる関節卜 ルク推定では, 推定誤差の要因としてつぎのようなものが考 えられる。

（1） 装着者ごとの筋発揮力または関節トルクと $\mathrm{EMG}$ と の相関

（2）装着者の体格差に伴うスーツの伸縮差による測定位 置誤差

（3）装着ごとの測定位置の初期位置䛊差

(4) 動作中の測定位置のずれ

（5）動作中の EMG センサと皮䖉との接触性，つまりイ ンピーダンスの変化

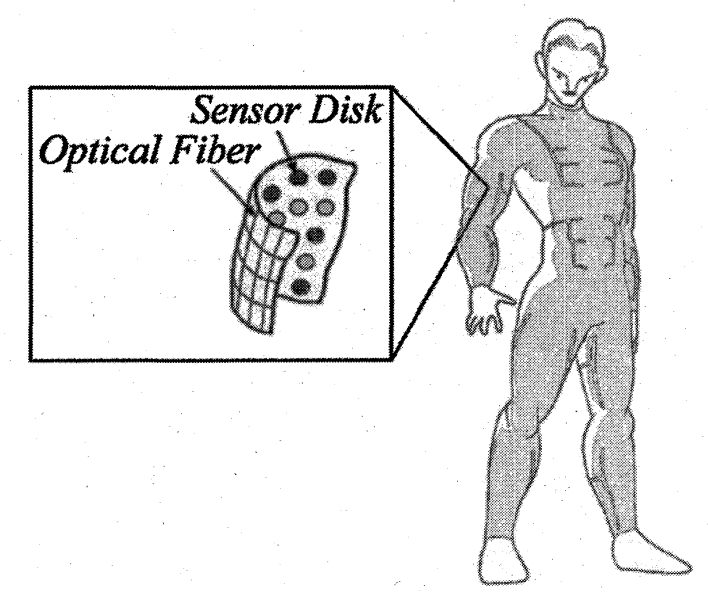

Fig. 1 Conceptual image of sensor suit

（6）センサの故障や電気的ノイズなどの不具合

要因 (1), (2) は装着者の身体的特徵によるものであり個人差 と考えられる。要因 (3)，(4) は主にセンサデバイスと装着者 との位置関係によるものであり測定位置誤差と考えられる。 要因 (6) は予期することが困難であるため, 本研究では無視 することとする。ここで, 本研究ではスーツに EMG センサ を内蔵するのではなく，直接皮膚に貼り付け，後述するセン サ基準位置からの位置誤差を正確に測定できるようにした。 これに伴い, 要因 (5) も無視できるものとした.

以上より，本研究では EMG センサを皮膚に貼り付け実験 を行なうことによって，下肢 EMG センサスーツを用いた場 合に発生する推定誤差要因 (1) (4) が膝関節トルク推定に及 ぼす影響を明確にした上で，これらの影響を実験的に検証す るとともに，これらの誤差要因に対してロバストな推定シス テムを高速に構築する手法を提案する.

\section{EMG を用いたトルク推定システム}

\subsection{EMG 計測とセンサ基準位置}

EMG センサとして湿式表面皿型電極を用い，日本光電製 生体アンプ MME-3116 により EMG を計測した。生体アン プの増幅率は 5000 倍であり，カットオフ周波数がそれぞれ $10[\mathrm{~Hz}], 200[\mathrm{~Hz}]$ のハイパス，ローパスフィルタを適用した. また，装着ごとに電極にペーストを塗布した。電極間距離は $20[\mathrm{~mm}]$, アースは足首とした。

前述したとおり, 本研究では直接皮膚にセンサを貼り付ける が，スーツに内蔵することを考慮し，前述の推定誤差要因 (2) より体格によってスーツの伸縮度合いが変わるものとし, 足の 長さと太さからセンサ基準位置を定めた。ここで, 標準体型に おける大腿部断面図を Fig. 2 に示す ${ }^{13)}$ ．図中の RF,VI,VL が大腿四頭筋と呼ばれる伸筋群, SM,ST,BFI が大腿二頭筋, 半膜様筋, 半腱様筋と呼ばれる屈筋群である. 膝関節の屈伸 方向のトルクを推定するためには; これらの筋群の活動を知 る必要がある. そこで, Fig. 2 に基づいて, Fig. 3 のように 伸筋群に 4 箇所, 屈筋群に 3 箇所にセンサを取り付け, セン 


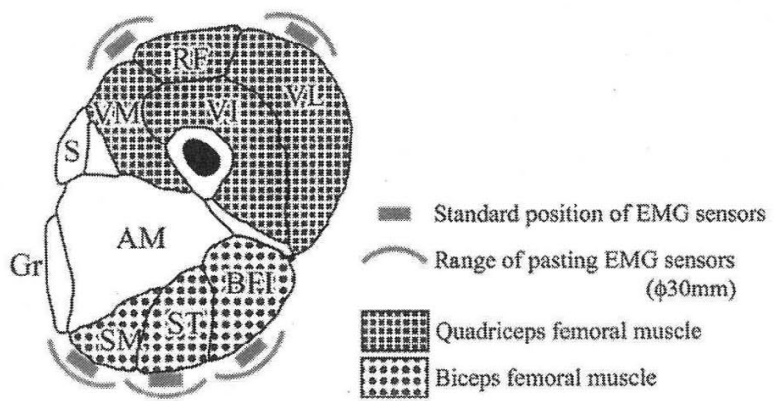

Fig. 2 Femoral muscles in section
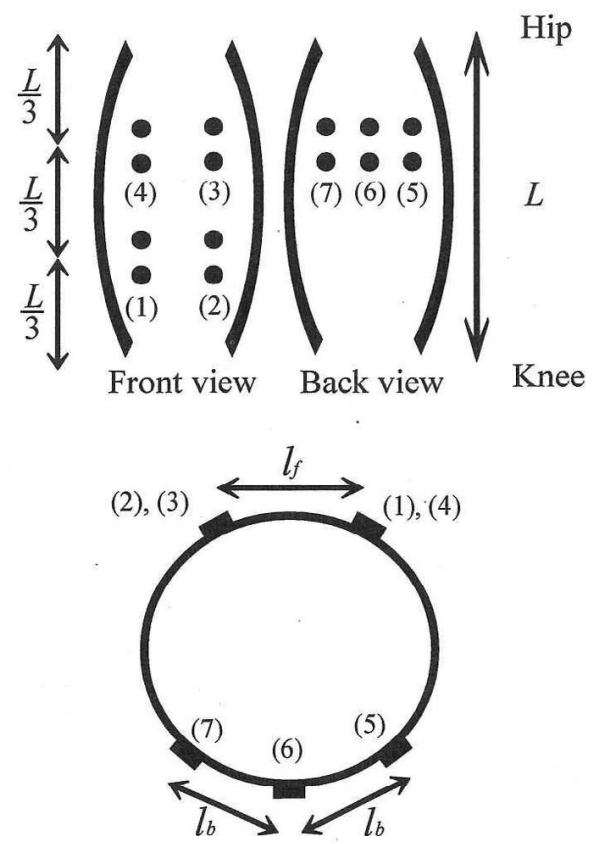

Overview of cross section

Fig. 3 EMG sensors' location on thigh

サ基準位置を同図のように定めた。つまり，Lは大腿部長さ (股関節-膝関節間距離),$l_{f}$ は四頭筋部の円周方向のセンサ 間距離であり， $l_{b}$ は二頭筋部の円周方向のセンサ間距離であ る. $l_{f}$ は大腿部中央での周囲の $1 / 8, l_{b}$ は同じく $1 / 10$ とす ることで, 大腿部伸筋, 屈筋群の筋活動計測に適切なセンサ 位置となるようにした，後述する実験での被験者 10 人の七 ンサ基準位置 $\left(L, l_{f}, l_{b}\right)$ を Table 1 に示す.

\section{2 教師データの獲得}

被験者の膝関節トルクを計測するために土台と 1 リンクアー ムから構成されるトルク測定器を作成した (Fig. 4). 滕を伸 ばした状態を 0 [deg] とすると,アームは $0 \sim 120$ [deg] まで 滕屈曲方向に回転でき，ピンによってアームを土台に $15[\mathrm{deg}]$ ごとに固定できる。アームの先端に被験者の足首を固定し， 被験者の関節トルクによって生じた歪をアームの根元付近に 付けた 4 つの歪ゲージで計測し，アンプ，AD 変換ボードを 通してPCに記録した。この測定値より，アームに加わった トルクを算出し，トルク推定システムの教師データとした。
Table 1 EMG sensor location of each testee

\begin{tabular}{|c|c|c|c|}
\hline Testee & $L[\mathrm{~mm}]$ & $l_{f}[\mathrm{~mm}]$ & $l_{b}[\mathrm{~mm}]$ \\
\hline A & 430 & 75 & 60 \\
\hline B & 400 & 49 & 39 \\
\hline C & 395 & 53 & 43 \\
\hline D & 430 & 51 & 41 \\
\hline E & 425 & 60 & 48 \\
\hline F & 380 & 65 & 52 \\
\hline G & 420 & 63 & 51 \\
\hline H & 420 & 56 & 45 \\
\hline I & 415 & 59 & 47 \\
\hline J & 450 & 60 & 48 \\
\hline
\end{tabular}
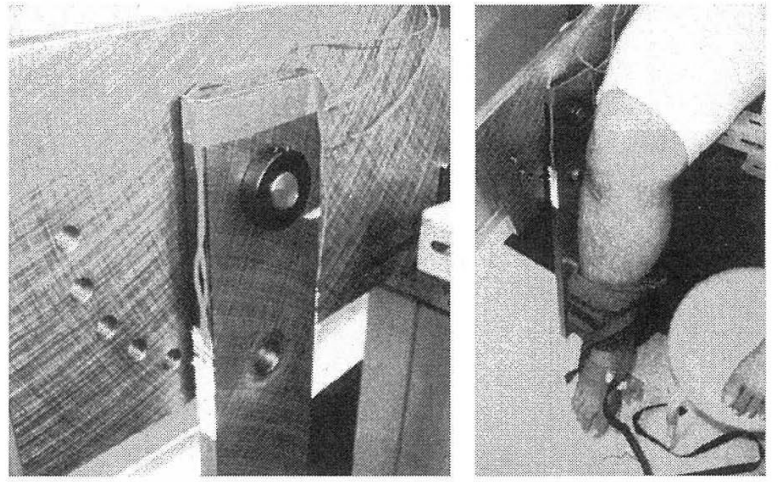

Fig. 4 Torque sensor for obtainig teaching signals

\section{3 トルク推定システム}

EMG からトルクを推定する手法として，線形手法である 重回帰分析と非線形手法であるニューラルネットワーク（以 下，NN）を用いた推定システムをそれぞれ構築した。いず れも FMG $7 \mathrm{ch}$ と膝関節角度を入力とし出力を関節トルクと した.

本研究では，まず両手法の個人差，装着位置誤差の影響を 調べる。つぎに個人差，装着位置誤差が少ない推定手法を基 盤として，よりロバストで高速な推定システムの構築手法を 開発する.

3.3 .1 重回㷌分析による線形トルク推定 重回帰分析には次式を用いた。

$$
\begin{array}{rl}
\tau=\mathbf{A} \cdot \mathbf{r} & \mathbf{A}=\left[\begin{array}{lllll}
a_{0} & a_{1} & \cdots & a_{8}
\end{array}\right] \\
\mathbf{r} & =\left[\begin{array}{llllll}
1 & E_{1} & E_{2} & \cdots & E_{7} & \theta
\end{array}\right]^{T}
\end{array}
$$

ここで, $\tau$ は膝関節トルク, $E_{i}(i=1 \sim 7)$ は Fig. 3 に示す各セ ンサから得られる EMGの整流積分值 (積分時間 $1[\mathrm{sec}]$ ), $\theta$ は 膝関節角度,つまりトルクセンサのアーム角度, $a_{i}(i=0 \sim 8)$ は重回帰係数である。トルクセンサにより $\tau$ の真值を得て, 重回帰分析によって係数を求めた.

3.3.2 ニューラルネットワークによる非線形トルク推定 非線形的なトルク推定を行なうために, Fig. 5 に示す階層 型 NN を用いた。入力は重回帰分析同様，各 EMG の積分值 および膝関節角度である。 入力層, 中間層の伝達関数には対 


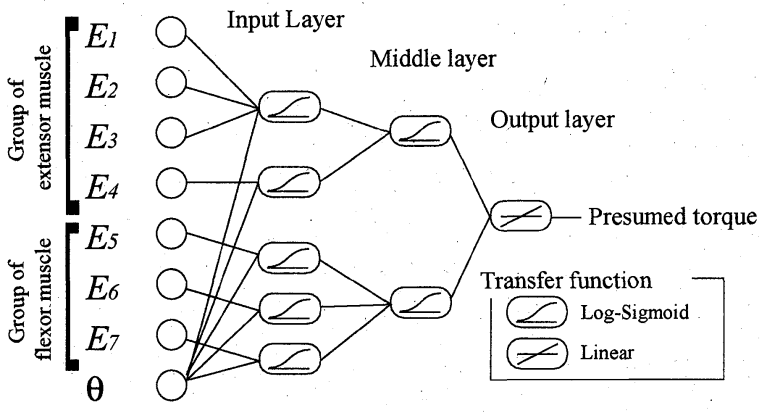

Fig. 5 Neural network for estimating knee joint torque

数シグモイド伝達関数, 出力層には線形伝達関数を適用した. トルクセンサにより膝関節トルクの教師信号を得て，バック プロパゲーションにより重みを学習した，中間層まで，大腿 四頭筋部 EMG 4ch と二頭筋部 EMG 3ch に分け, 学習に要 する時間を軽減した。・初期状態として各重みをランダムに変 化させ，その状態から学習を行なった。

\section{4. トルク推定実験}

\section{1 トルク推定システムの調整}

被験者は 10 人とし，膝関節角度を $30 \sim 105[\mathrm{deg}]$ の間で $15[\mathrm{deg}]$ 刻みに, 各 EMG の積分値, 膝関節角度およびトル クを計測した。このとき各被験者の運動を統一することを考 慮し, 被験者の膝関節トルクの計測值と目標卜ルクをディス プレイに表示して，できる限り目標トルクに追従するよう被 験者に指示した。目標トルクは, $-40.0 \sim 40.0[\mathrm{Nm}]$ の範囲 で, 30 秒ごとに $8.0[\mathrm{Nm}]$ ずつステップ状に変化するものと した.

各被験者ごとに, 教師用データとして 3 回計測して，(1) 式 の重回帰係数の獲得と NN の重みの学習を行なった.ここで $\mathrm{NN}$ の学習において, NN 出力と教師デー夕の二乗平均平方 根誤差 (root mean square of error，以下 RMSE とする) が $2.0[\mathrm{Nm}]$ 以下となった場合に学習を終了した.

つぎに検証用データを 2 種類計測した。

Case 1 教師デー夕計測時とセンサ位置を变えずに計測.

Case 2 教師デー夕計測時から Fig. 2 に示すように直径 $30[\mathrm{~mm}]$ の円内ですべてのセンサをランダムにずらして計測. Case 2 に抢ける $30[\mathrm{~mm}]$ という数值は, 大腿部の筋肉配置か ら求めたものであり，これ以上ずれが大きくなるとほかの筋 肉を計測する恐れがある。また，経験的に知り得たスーツの ずれより, Case 2 に扔いて，ずれの上限を $30[\mathrm{~mm}]$ とした。 センサスーツの作成においてもずれがこの範囲に収まるよう に作成する必要がある。これらの検証デー夕を各被験者ごと に調整した線形扔よび非線形卜ルク推定システムに入力し, 出力された推定トルクの計測したトルクに対するRMSE を 求めた。

Case 1 におけるRMSE Table 2 に示す. 全被験者の RMSE の平均は線形推定で $14.5[\mathrm{Nm}]$, 非線形推定で $4.3[\mathrm{Nm}]$ であった。また，Case 2 に扔けるRMSEを Table 3 に示
Table 2 RMSE of torque estimation on Case 1

\begin{tabular}{|c|c|c|}
\hline Testee & $\begin{array}{l}\text { Linear } \\
\text { estimation }[\mathrm{Nm}]\end{array}$ & $\begin{array}{l}\text { Non-linear } \\
\text { estimation }[\mathrm{Nm}]\end{array}$ \\
\hline $\mathrm{A}$ & 14.3 & 4.4 \\
\hline $\mathrm{B}$ & 14.6 & 3.7 \\
\hline $\mathrm{C}$ & 10.6 & 3.1 \\
\hline $\mathrm{D}$ & 19.4 & 5.0 \\
\hline $\mathrm{E}$ & 18.6 & 3.9 \\
\hline $\mathrm{F}$ & 14.7 & 5.2 \\
\hline $\mathrm{G}$ & 16.1 & 4.6 \\
\hline $\mathrm{H}$ & 12.6 & 5.4 \\
\hline $\mathrm{I}$ & 11.8 & 3.5 \\
\hline J & 12.7 & 4.3 \\
\hline \hline Ave./S.D. & $14.5 / 2.8$ & $4.3 / 0.8$ \\
\hline
\end{tabular}

Ave.: Average, S.D.: Standard deviation

Table 3 RMSE of torque estimation Case 2

\begin{tabular}{|c|c|c|}
\hline Testee & $\begin{array}{l}\text { Linear } \\
\text { estimation }[\mathrm{Nm}]\end{array}$ & $\begin{array}{l}\text { Non-linear } \\
\text { estimation }[\mathrm{Nm}]\end{array}$ \\
\hline $\mathrm{A}$ & 28.2 & 7.7 \\
\hline $\mathrm{B}$ & 23.4 & 6.9 \\
\hline $\mathrm{C}$ & 16.0 & 9.5 \\
\hline $\mathrm{D}$ & 19.6 & 5.1 \\
\hline $\mathrm{E}$ & 19.4 & 4.5 \\
\hline $\mathrm{F}$ & 28.2 & 13.3 \\
\hline $\mathrm{G}$ & 26.1 & 6.0 \\
\hline $\mathrm{H}$ & 17.2 & 6.1 \\
\hline $\mathrm{I}$ & 20.9 & 3.9 \\
\hline J & 16.2 & 19.6 \\
\hline \hline Ave./S.D. & $21.5 / 4.7$ & $8.3 / 4.8$ \\
\hline
\end{tabular}

す. 全被験者の RMSE の平均は線形推定で $21.5[\mathrm{Nm}]$, 非線 形推定で 8.3[Nm] であった.

線形推定と非線形推定の推定誤差の関係を Table 4 亿表 わす．NNを用いた非線形推定は，Case 2 の被験者、Jで線形 推定に比べて誤差が $21 \%$ 増加するなど個人差も認められた が，そのほかの被験者では誤差が減少して㧍り，全被験者の 平均で約 $65 \%$, 線形推定に比べて誤差を削減できることが確 認され，センサスーッでのトルク推定に有効であることが示 された。ただし，非線形推定の場合でも，平均值で約 5-10\% のトルク推定誤差が生じた.

\section{2 測定位置誤差によるトルク推定の影響}

4.1 節で得られた各個人用のトルク推定システムを用いて, すべてのセンサを一定方向に 10,20,30 [mm] とずらして得 られた EMG データからトルク推定した際の RMSE の全被 験者平均と標準偏差を Fig. 6 に示す.

実験結果より, 非線形推定の線形推定に対する推定誤差増 加率が位置誤差をもたないときは $71 \%$ なのに対して, $30 \mathrm{~mm}$ の位置誤差データに対しては $92 \%$ と增加し, 線形推定に対し て非線形推定の位置誤差に対するロバスト性を確認した。し かし, 非線形推定に扔いても, 誤差が測定位置誤差に対して より頑強な推定システムの構築が望まれる。

\section{3 個人差によるトルク推定の影響}

4.1 節で得られたトルク推定システムを用いて, ほかの被験 
Table 4 Reduction of RMSE of torque estimation

\begin{tabular}{|c|c|c|}
\hline Testee & Case 1[\%] & Case 2[\%] \\
\hline $\mathrm{A}$ & 69 & 73 \\
\hline $\mathrm{B}$ & 75 & 71 \\
\hline $\mathrm{C}$ & 71 & 41 \\
\hline $\mathrm{D}$ & 74 & 74 \\
\hline $\mathrm{E}$ & 79 & 77 \\
\hline $\mathrm{F}$ & 65 & 53 \\
\hline $\mathrm{G}$ & 71 & 77 \\
\hline $\mathrm{H}$ & 57 & 65 \\
\hline $\mathrm{I}$ & 70 & 81 \\
\hline $\mathrm{J}$ & 66 & -21 \\
\hline \hline Ave./S.D. & $70 / 6.1$ & $59 / 31$ \\
\hline
\end{tabular}

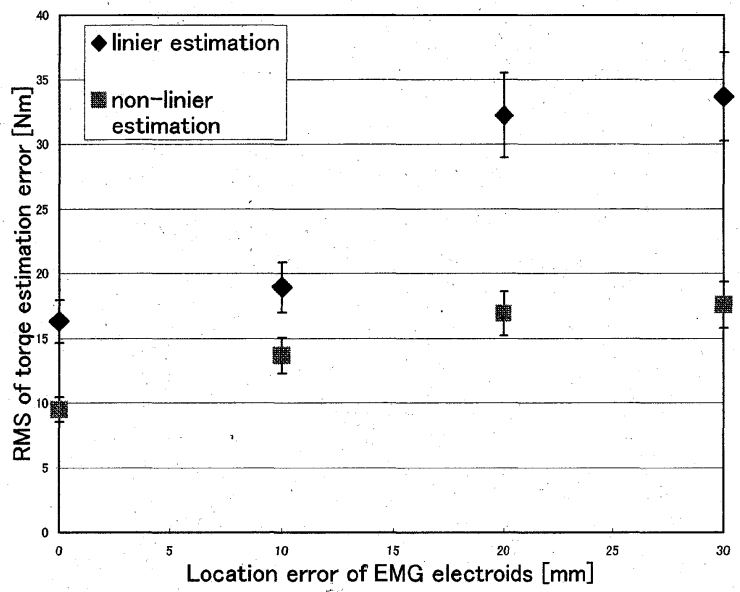

Fig. 6 Relation between RMSE of torque estimation and location error of EMG electrodes

Table 5 Relation between RMSE on torque estimation and individual difference

\begin{tabular}{|l|c|c|}
\hline Testee & $\begin{array}{l}\text { Linear } \\
\text { estimation }[\mathrm{Nm}]\end{array}$ & $\begin{array}{l}\text { Non-linear } \\
\text { estimation }[\mathrm{Nm}]\end{array}$ \\
\hline Case1 & $29.7(105[\%])$ & $11.2(160[\%])$ \\
\hline Case2 & $34.4(60[\%])$ & $11.5(39[\%])$ \\
\hline
\end{tabular}

者の推定システムによりトルク推定した際の RMSE の平均 值を Table 5 に示す. 括弧内の数值は個人ごとに推定を行 なった結果からの誤差の平均増加率である. なお, 誤差の増 加率は個人ごとに推定を行なった誤差に対するパーセンテー ジで求めた。

結果より， NNを用いた場合にも個人差の影響は大きく， ユーザーに適した推定システムを構築する必要があるといえ る，ここで，4.1節で得られた NN を用いたトルク推定シス テムの学習回数は 10 人の被験者で平均 1148 回であり,.多 くの学習時間を要している. 学習時間は計算機の能力に依存 するが, 本研究で使用した PC (CPU : Pentium $42.4 \mathrm{GHz}$, Memory : 256MB) では, 平均で約 46 秒である. ユーザー 個人に適したトルク推定システムの学習, つまりシステム構 築を短時間で行なうことができれば，センサスーツの実用性 を向上することができる。なお，線形推定におけるシステム 構築時間は約 1 秒であった。本研究ではこの構築時間を基準
としてシステム構築の高速化を目指す.

\section{5. 共有データを用いたロバスト関節トルク推定システ ムと高速較正}

$\mathrm{NN}$ が EMG を用いた高精度かつロバストな関節トルク推 定に適していることが確認されたが，較正に時間を要すると いった問題がある。そこで，本研究では共有 NNを用いたシ ステムを提案する.

\section{1 共有 $\mathrm{NN}$ の作成}

共有 $\mathrm{NN}$ は各被験者の教師デー夕を, 無次元化, 平均化 することによって得られた共有デー夕を用いて学習を行なっ た NNである．このような NNを作成することによって，複 数の装着者に適用できる一般的な傾向をもった推定システム を構築できると考えた．無次元化の目的は電極の接触抵抗や 皮下脂肪など，筋発揮力と EMG の関係性に線形的な影響を あたえる個人差を補正することである。各被験者において各 EMG チャンネルに平均值を求め, その值で EMG を割る方 法を用いた。これによって被験者 $\mathrm{n}(\mathrm{n}=1 \sim 10)$ の時系列デー 夕セット $D_{n}(t)=\left\{E_{n}(t), \theta_{n}(t), T_{n}(t)\right\}$ から，(2) 式に示す ように無次元化時系列データセット $D a_{n}$ を作成した。ここ で $E_{n}(t)$ は整流積分 $\mathrm{EMG}, \theta_{n}(t)$ は関節角度, $T_{n}(t)$ は計 測トルクである. また $T$ は時系列ごとのデータセット数で ある。

$$
\begin{aligned}
D a_{n}(t) & =\frac{D_{n}(t)}{\operatorname{ave}\left(D_{n}(t)\right)} \\
\operatorname{ave}\left(D_{n}(t)\right) & =\frac{\sum_{t=1}^{T} D_{n}(t)}{T}
\end{aligned}
$$

つぎに，無次元化したデータセットを被験者全体で平均化す ることによって個人差の影響を軽減した一般的なデータセッ 卜を作成する。しかしながらこの時点でデータセットは時系 列で並んでいるため，そのままの順序で平均を求めても，被験 者ごとに計測状態が異なるため，正しい傾向を得ることがで きない. そのため, 計測トルクの大きさで並び替えを行ない, 計測トルクの大きさを順に並んだデータセット $D a_{n}(\tau)$ を作 成した.このデータセットの平均を求め共有デー夕 $D u(\tau)$ を 作成した．式を (3) に示す。この共有データを用いて NNの 初期状態から学習を行ない共有 NN を作成した

$$
\begin{aligned}
D u(\tau) & =\frac{\sum_{n=1}^{N} D a_{n}(\tau)}{N} \\
N & : \text { 共有データ作成に用いる被験者数 }
\end{aligned}
$$

\section{2 共有 $\mathrm{NN}$ によるトルク推定}

共有 $\mathrm{NN}$ は，ある集団の平均的な $\mathrm{EMG}$ と関節トルクとの 関係を表わした NN である. まず，共有 NN のトルク推定性 能を実験的に検証する。

ここで，つぎのような条件で共有 NN を作成した。

（1）被験者群は前節までと同様とした。 
（2）共有データの作成に反映する被験者数（以下，共有 デー夕作成人数とする）を $1 \sim 9$ 人の 9 通りとした。

（3）学習終了条件を RMSE が閾值以下になった場合と し，その值は 1.0, 3.0, 5.0, 8.0, 10.0[Nm]の 5 通りとした. （4）共有デー夕作成人数と学習終了条件の RMSE をそ れぞれ変化させ，各条件で 10 回ずつ共有 NNを作成した。 共有 NN が一般的な傾向をもっているかを評価するために， 共有データの作成に用いた被験者データとトルク推定に用い た被験者デー夕は別々のものを使用した。よって，N 人で共 有 NN を作成した場合には残り (10-N) 人でトルク推定を行 なう。共有データ作成人数ごとにランダムに 10 通りの被験 者組み合わせを選び，検証を行なった，以上のように作成さ れた共有 NNを用いて，共有デー夕の作成に使用しなかった 被験者の検証用データ Case 1 および 2 に対してトルク推定 を行なった。

共有データ作成人数と学習終了条件がトルク推定精度に与 える影響を Fig.7 に示す、図中において，N は共有データ 作成に用いた被験者数, $\mathrm{E}_{e}$ は共有 $\mathrm{NN}$ の学習精度, $\mathrm{E}_{t}$ は卜 ルク推定誤差である.

図示するとおり， $N \geq 4$ では $E_{e}$ が低くなるほど推定精度 が上昇するのに対し， $N \leq 3$ では $E_{e}$ を 3.0 より低くした場 合に推定精度が著しく悪化することが確認された。

\section{3 トルク推定システムの高速較正}

5.1 節で作成した共有 NN を NN 学習の初期值とし，そこ から無次元化した各被験者の教師デー夕によって追学習を行 なうことによって，各被験者用にトルク推定システムを較正 した。追学習は共有データの作成に使用しなかった被験者の 教師データで行ない，また 4.1 節と同様に，NN 出力と教師 データの RMSE が 2.0[Nm] 以下となった場合に，追学習を 終了した.

前述の共有 $\mathrm{NN}$ の作成条件と，追学習に要した平圴学習回 数および平均学習成功確率の関係を Fig. 8 に示す。ここで， 学習成功確率とは，学習回数が 5000 回以内に学習終了条件 に達する確率である。これにより， $E_{e}$ が小さいはど，追学 習に要した回数，つまり較正に要する時間を短縮することが でき，かつ学習成功確率を上げることができるといえる。一 方， $N$ は，較正時間，学習成功確率ともに影響しないことも 確認できた。

つぎに，4節で示した初期状態から各被験者の教師デー夕 のみでトルク推定 NN を較正した場合と， $N=9$ の共有 NN から追学習して較正した場合の平均学習回数および平均学習 成功確率を Table 6 で比較する。これにより，共有 NN か ら較正した場合は，学習回数を 1148 回から 112 回と大幅に 短縮でき，かつ学習成功確率を $60 \%$ から $90 \%$ に向上できるこ とを確認した。本研究で使用したPCでは，共有 NNを用い たトルク推定システムの較正に要する時間は平均で約 4.6 秒 であり，前述の線形推定システムの構築時間に比べて，十分 に高速な較正手法であるといえる。

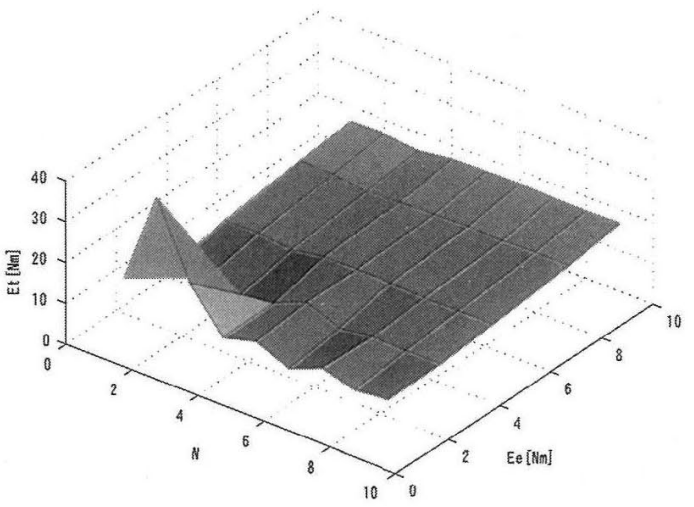

(a.) Case 1

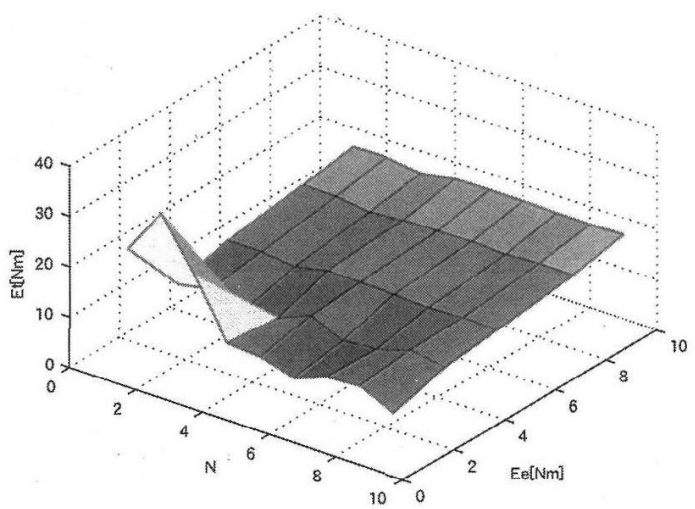

(b) Case 2

$\mathrm{N}$ :Number of subject for making universal NN

$\mathrm{E}_{e}: \mathrm{RMSE}$ of end-of-learning condition for making universal NN $\mathrm{E}_{t}: \mathrm{RMSE}$ on torque estimation

Fig. 7 RMSE on torque estimation using universal NN

\section{4 追学習したトルク推定システムにおける測定位置誤 差の影響}

5.3 節で述べた追学習 NN を用いたトルク推定システムを 用いて，各被験者の検証用データ Case 1 および 2 でのトル ク推定を行なった結果を Fig.9 に示す。また $E_{e}=1.0$ に㧈 ける推定誤差と，個人 NN との誤差減少率を Table 7 に示 す。これにより，初期状態からの学習に対して，共有 NN か ら較正することによって, Case 1 においては誤差が大きくな るものの，検証用データ Case 2 に対する推定誤差が小さく なることが確認された。 $N=9$ の場合では, Case 1 では誤 差が $26 \%$ 増加，Case 2 では $28 \%$ 減少している。また，全 般的に $E_{e}$ が小さくなるほど $E_{t}$ が小さく，つまり推定精度 が上昇しているが，N が少ない場合は学習終了条件を厳しく すると若干推定精度が低下した

\section{5 高速較正システムに対する個人差の検証}

共有 NNを用いたトルク推定システムの構築方法は従来の 方法に対して，高速に個人デー夕に適合したシステムを構築 できることが確認できた。しかし，これまでに提示してデー 夕は 1 つの共有 $\mathrm{NN}$ の作成条件に関して複数の被験者デー夕 


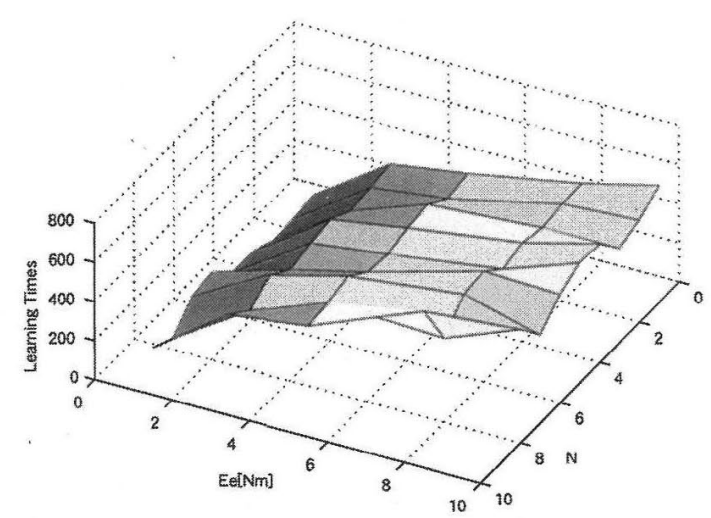

(a)learning times of successful learning

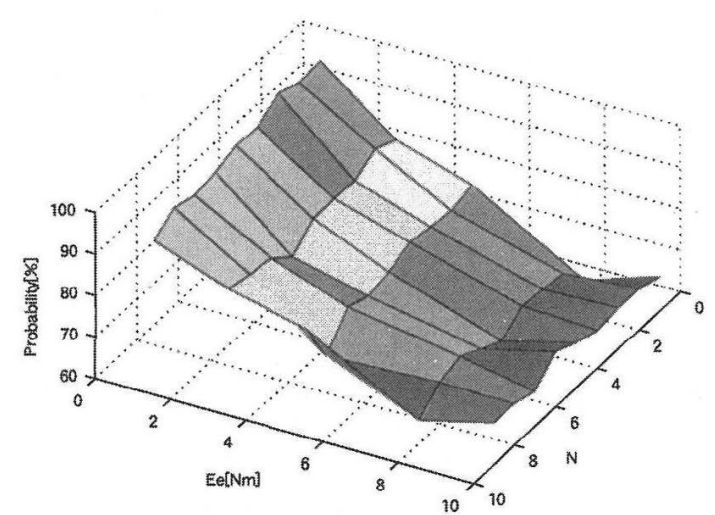

(b)probability of successful learning

Fig. 8 Learning times and probability of successful learning on calibration using universal $\mathrm{NN}$

Table 6 Relation during end-of-learning condition for learning universal NN, learning times and probability of successful learning

\begin{tabular}{|c|c|c|}
\hline $\mathrm{E}_{e}$ & Learning times & Probability [\%] \\
\hline No learning & 1148 & 63 \\
\hline 10 & 702 & 70 \\
\hline 8.0 & 670 & 65 \\
\hline 5.0 & 438 & 80 \\
\hline 3.0 & 386 & 84 \\
\hline 1.0 & 112 & 91 \\
\hline
\end{tabular}

で検証を行なった結果であり，共有 NNを用いたシステムに 対して被験者ごとの個人差が与える影響を考える必要がある。 そこで，推定精度の検証に拈いて各共有 NN から追学習した トルク推定システムの推定精度の標準偏差を求めた。その結 果Fig. 10 をに示す。これより $N$ が少ないときと $E_{e}$ が大 きいときに標準偏差が大きくなる傾向を見ることができた。

\section{6 . 考察}

まず， 5.2 節で共有 NN を用いてトルク推定を行なった。 Fig. 7 の結果より共有 NN では個人のトルク推定精度はそれ ほど高くないが，作成人数を増やすことによって各個人ごと に調整したNNでは困難であった個人差の影響を吸収し被験 者全体に対してある程度の推定精度を確保できるシステムを

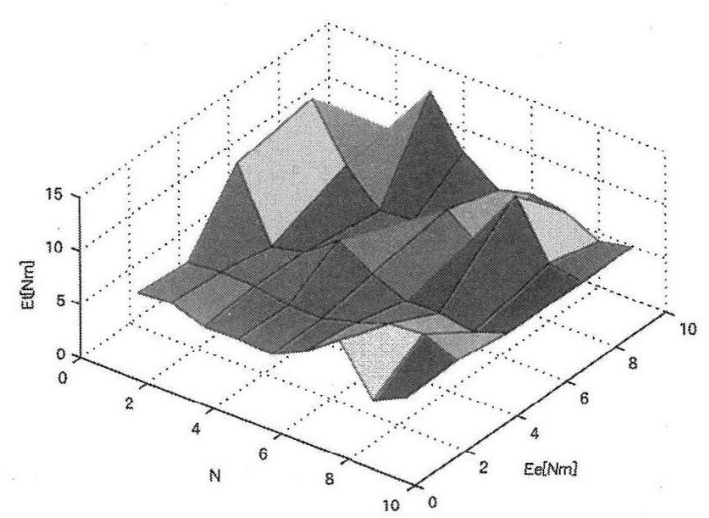

(a) Case 1

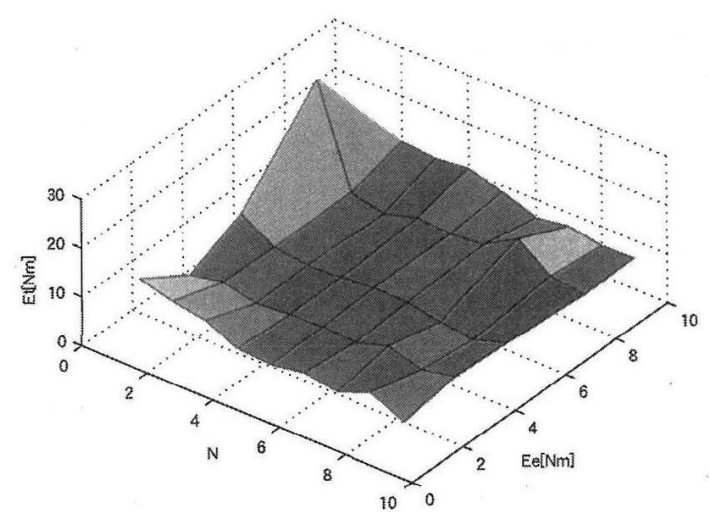

(b) Case 2

Fig. 9 RMSE on torque estimation using additional training NN

Table 7 RMSE on torque estimation using additional training $\mathrm{NN}\left(E_{e}=1.0, N=9\right)$

\begin{tabular}{|c|c|c|c|c|}
\hline $\mathrm{m}$ & case $1[\mathrm{Nm}]$ & casc $2[\mathrm{Nm}]$ & casc 1[\%] & case 2[\%] \\
\hline Initial & 4.3 & 8.3 & 0 & 0 \\
\hline 1 & 5.67 & 12.8 & -32 & -54 \\
\hline 2 & 5.88 & 11.0 & -37 & -33 \\
\hline 3 & 4.82 & 9.8 & -12 & -19 \\
\hline 4 & 4.88 & 6.84 & -13 & 17 \\
\hline 5 & 4.61 & 6.23 & -7 & 24 \\
\hline 6 & 6.08 & 7.39 & -41 & 11 \\
\hline 7 & 8.33 & 6.35 & -93 & 23 \\
\hline 8 & 3.97 & 9.17 & 7 & -0.1 \\
\hline 9 & 5.43 & 5.94 & -26 & 28 \\
\hline
\end{tabular}

作成することができた。これは共有データという沈用性の高 いデータで NNを学習することによって，複数の被験者から 求めた，一般的な筋骨格モデル，EMGと筋発揮力などの関 係性にもとづいたトルク推定システムが構築できるものと考 えられる。また， $N$ が少ない場合は $E_{e}$ を小さくした場合に 誤差が大きくなった。このことは，個人差の影響を吸収した データで学習を行なわなかったため, 過学習が起こったこと が原因と考えられる。

つざに, 5.3 節において共有 NN から各個人用トルク推定シ ステムを構築する追学習を行ない Fig. 8 の結果より，学習回 


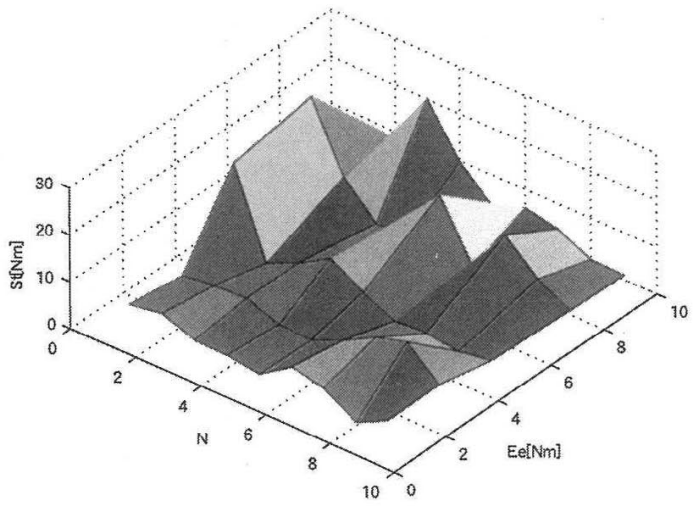

(a) Case 1

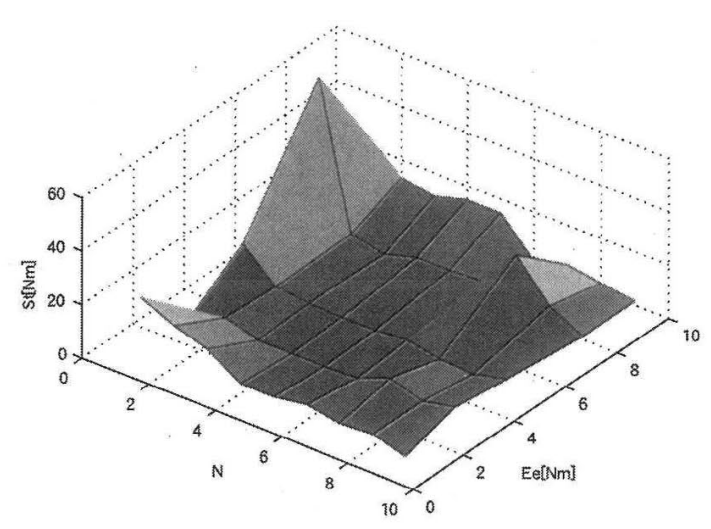

(b) Case 2

$\mathrm{S}_{t}:$ Standard deviation on torque estimation

Fig. 10 Standard deviation of error on torque estimation using additional training $\mathrm{NN}$

数・成功確率ともに飛躍的な改善が認めることができた。こ のことから個人差が含まれているデー夕を用いた NNでも高 い推定精度まで学習を行なえば，追学習を行なうことによって 学習性能が向上することを確認できた。 これは, 今回提案し たシステムで EMGの無次元化を行なうことによって，皮下 脂肪の量や電極の皮膚への接触抵抗などの筋発揮力と EMG の関係性に線形的な影響を与える要因の個人差を軽減できた ことから各被験者ごとの教師データが近い傾向を示したため と考えられる。

さらに，5.4，5.5 節において共有 $\mathrm{NN}$ を追学習した NN を 用いてトルク推定を行ない, その推定誤差と推定誤差の標準 偏差を求めた。これより，全体的な EMG と関節トルクとの 関係を示す共有 NN を各個人用に追学習することによって， 個人に適応したトルク推定システムを高速に構築できるとと もに，その推定システムが Case 1 に関しては誤差が大きく なるものの, Case 2 に関しては誤差を約 $30 \%$ 減少させる結 果を示した。これによって測定位置誤差と個人差に対してロ バストな推定システムを構築することができたといえる.

\section{6. 結論}

EMG を内蔵したウェアラブルセンサスーツのためのロバ ストな関節トルク推定システムとその高速較正手法を提案し た。本研究の結果を以下にまとめる。

（1）推定にNN を使用した結果，重回帰分析を用いた推 定システムに対して，推定誤差を 60〜70\% 削減できること を確認した。

（2）センサ位置をずらしたデー夕を用いて，各推定方法 に扔ける位置誤差に対するロバスト性を検証した。その結 果，線形推定の推定誤差が非線形推定にたいして $71 \%$ に 対して $92 \%$ と増加し, 非線形システムが位置誤差に対し て高いロバスト性を示した。

（3）個人データで学習行なった NN を用い他人のトルク 推定を行なった。その結果本人のデータで学習を行なった 結果に対して，線形推定において 60，105\%，非線形推定 において 40，160\% 誤差が増加するのを確認し，トルク推 定における個人差の影響を確認した.

（4）共有 NN を個人の教師データで追学習することに よって, 初期化状態の $\mathrm{NN}$ からの学習に対して, 学習回 数,つまり較正時間を $90 \%$ 短縮でき, かつ学習成功確率を 60\%〜90\%に向上できることが確認された.

（5）追学習によって得られたNNを用いてトルク推定を 行ない, このシステムが初期化状態から個人のデータのみ で学習した NN に対して，位置誤差を含んだデー夕におい て約 30\%の推定誤差を削減できることを確認した。

(1), (2) より EMG センサスーツでの関節トルク推定には NN を用いた非線形推定システムが望ましいことを確認した。ま た，(3) より複数人のデータで学習した共有 NN が一般的な 傾向をもった推定システムであることを確認した。さらに， (4), （5）より共有 NN を追学習する手法は, 測定位置誤差と 個人差に対してロバストな関節トルク推定システムの構築と 高速な較正に有効であることを確認した。

\section{参 考 文 献}

1) Osamu Fukuda, Toshio Tsuji, et. al.: A Human-Assisting Manupulator Teleoperated by EMG signals and Arm Motions, IEEE Transactions on Robotics and Automation, 19-2, 210/222 (2003)

2) 田中, 松永, 堀：移動ロボットの脳動制御, 電気学会論文誌. C, 電子 ・情報・システム部門誌, 124-3, 890/896 (2004)

3）小川, 木竜, 斉藤：筋活動状態を考慮した自転車エルゴメータ の負荷制御，電子情報通信学会論文誌. D- 2 , 情報・システム 2-情報処理，J81-D-2-2, 421/428 (1998)

4）田中，山口，諸麦，マリア Q. フェン：ウェアラブルセンサスー ツ(第 1 報)，日本ロボット学会創立 20 周年記念学術講演会, 1 F24 (2002)

5）梶谷, 星野, 西川, 横井, 梶原, 桶口：障害者に適応可能な筋電 操作型義手の開発，電子情報通信学会技術研究報告. PRMU, 98, 9/16 (1998)

6）森田，柴田，鄭，伊藤：ニューラルネットワークを用いた人 間-筋電義手インタフェース, 電子情報通信学会技術研究報告. MBE，ME とバイオサイバネティックス，99, 37/42 (2000) 
7) Yasuharu Koike and Mitsuo Kawato: Estimation of dynamic joint torques and trajectory formation from surface electromyography signals using a neural network model, Biological Cybernetics, 73-4, 291/300 (1995)

8) C.J., De Luca: Myoelectrical manifestations of localized muscular fatigue in humans, CRCCrit. Rev. Biomed. Eng, $11,251 / 279(1985)$

9）羽下, 芝井, 木竜: 双極表面筋電図計測のための電極貼付位置決 定プログラムの開発，電子情報通信学会技術研究報告. $\mathrm{MBE}$, 102-89, 29/32 (2002)

10）木竜徹：-口伝表面筋電位図編-, バイオメカニズム学会誌, 25-3 (2001)

11) Takayuki Tanaka, et. al.: Ultrasonic Sensor Disk for Detecting Muscular Force, IEEE International Workshop on Robot and Human Communication (CD-ROM), 5A3 (2003)

12) Yoichiro Tsutsui, Takayuki Tanaka, et. al.: Torque Estimation Using Ultrasonic Muscle Activity Sensor, International Conference on Advanced Mechatronics (CDROM), TP1-C-2 (2004)

13）福永哲夫, 共著: 筋の科学辞典一構造・機能・運動一, 朝倉書 店 $(2002)$

14）内山, 赤澤：ヒト时関節伸筋の筋活動度一角度一等尺性卜ル ク関係と一負荷卜ルク一速度関係, バイオメカニズム学会, バ イオメカニズム 14, 27/37 (1998)

15）金子，増田，車谷，村上，山根：急速な運動の動作分析を目的 としたワイヤ電極による筋電図記録方法の改良, 理学療法学, 30-5, 280/287 (2003)

16）金子，増田，車谷，村上，山根：動的運動時表面筋電図の計測 々解析, 月本顎口腔機能学会雑誌, 1-2, 233/241 (1995)

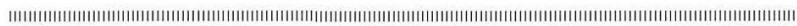

\section{[著 者 紹 介]}

鈴 木 洋 輔

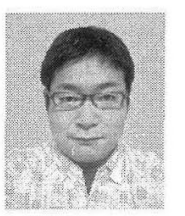

2004 年電気通信大学知能機械工学科修了. 同 年電気通信大学院電気通信学研究科知能機械工学 専攻入学. 生体計測を中心としたマシンインター フェイスの研究に従事。

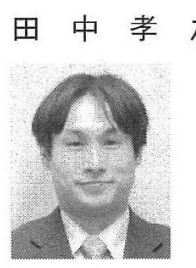

(正会員)

1996 年電気通信大学大学院電気通信学研究科 博士前期課程修了. 同年電気通信大学機械制御工 学科助手, 2001 年カリフォルニア大学アーバイン 校客員研究員, 2003 年電気通信大学知能機械工学 科助教授, 2004 年北海道大学大学院情報科学研究 科助教授, 現在に至る。ウェアラブルロボット， ヒューマンインタフェース，ユニバーサルデザイ ン, 移動ロボットの研究に従事 (工学博士).

$$
\text { マリア Q. フェン }
$$

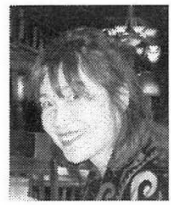

Maria Q. Feng is Professor of Civil and Environmental Engineering at University of California, Irvine (UCI). With Ph.D. in Mechanical Engineering from University of Tokyo, she joined UCI in 1992. Her research interests are primarily in the fields of innovative and interdisciplinary science and technology for sensors and health monitoring of human and structural systems.

\section{諸 麦 俊 司}

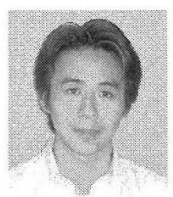

2003 年カリフォルニア大学アーバイン校 Ph.D 課程修了. 2002 年長崎大学上学部機械システム工 学科助手. 2004 年 -2005 年中国清華大学および韓 国科学技術院 (KAIST) 客員研究員, 現在に至る。 福祉機器, 装着型動作支援装置, 生体情報計測シ ステムの研究に従事 (工学博士).

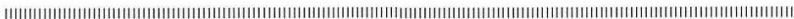

